\title{
Atrial Natriuretic Peptide and Renal Haemodynamics in Newborn Calves
}

\author{
A. DRATWA \\ Department of Animal Physiology, Faculty of Biotechnology and Animal Science, \\ Agricultural University of Szczecin, Str. Doktora Judyma 6, 71- 466 Szczecin, Poland \\ Received March 4, 2005 \\ Accepted March 16, 2006
}

\begin{abstract}
Dratwa A.: Atrial Natriuretic Peptide and Renal Haemodynamics in Newborn Calves. Acta Vet. Brno 2006, 75: 477-483.

The study was aimed to provide information on the dynamics of changes in the concentration of ANP in blood plasma of calves during the first seven days of their life and to find any association between blood plasma ANP concentration and effective renal blood (ERBF) and plasma flow (ERPF) and glomerular filtration rate (GFR). The experiment was carried out on 10 clinically healthy Black and White calves during the first seven days of postnatal life. The concentration of atrial natriuretic peptide (ANP) in blood plasma was determined with radioimmunoassay. The kidney function was assessed by clearance methods, using para-aminohippuric acid and inulin. The blood plasma ANP concentration increased with age. On the first day the mean concentration of ANP was $5.72 \pm 1.34 \mathrm{pmol} / 1$, on the $7^{\text {th }}$ day it was $14.34 \pm 2.09 \mathrm{pmol} / \mathrm{l}$. The ERBF and ERPF during the first week of life showed variations, mean ERBF ranging within $280.22 \pm 10.30 \mathrm{ml} / \mathrm{min} / \mathrm{m}^{2}\left(1^{\text {st }}\right.$ day) and $338.25 \pm 13.72 \mathrm{ml} / \mathrm{min} / \mathrm{m}^{2}$ ( $7^{\text {th }}$ day) and ERPF ranging between $179.77 \pm 8.27 \mathrm{ml} / \mathrm{min} / \mathrm{m}^{2}$ $\left(1^{\text {st }}\right.$ day) and $245.22 \pm 9.86 \mathrm{ml} / \mathrm{min} / \mathrm{m}^{2}$ ( $7^{\text {th }}$ day). The mean GFR on the first day was $35.68 \pm 2.10$ $\mathrm{ml} / \mathrm{min} / \mathrm{m}^{2}$ and significantly $\left(p \leq 0.01\right.$ ) increased on the second day $49.97 \pm 1.76 \mathrm{ml} / \mathrm{min} / \mathrm{m}^{2}$, subsequently GFR remained on a stabile level average $51.06 \mathrm{ml} / \mathrm{min} / \mathrm{m}^{2}$. The studies showed no correlations between plasma ANP concentration and ERPF (ERBF) and GFR. These data indicate that in calves during the first seven days of postnatal life endogenous ANP did not change the effective renal blood (plasma) flow and glomerular filtration rate.
\end{abstract}

ANP, kidneys, renal blood (plasma) flow, glomerular filtration rate

Atrial natriuretic peptide (ANP) is synthesised, stored, and released primarily by the myocytes of the atrium cordis. Increased blood volume and/or blood hydrostatic pressure contribute to the release of ANP to the circulation (Chapman et al. 1998; Chevalier et al. 1990a; Grant et al. 1996; Takemura et al. 1990).

It has been demonstrated that atrial natriuretic peptide receptors are located in many organs, including blood vessels, adrenal glands, pituitary gland, cerebellum, heart, small and large intestines; however, their highest number has been found in kidneys, i.e. in renal glomeruli, mesangium, the vessels of microcirculation, as well as in renal tubules ( $\mathrm{Ch}$ ai et al. 1986; Healy and Fanestil 1986; Lynch et al. 1986; Rutherford et al. 1994; Takeda et al. 1986; Wilcox et al. 1991).

Atrial natriuretic peptide may influence kidneys directly, affecting the functioning of the nephrons, or indirectly, modifying the haemodynamics of the kidney. It has been recognised that ANP, through influence on glomerular afferent and efferent arterioles, may also affect renal blood (and plasma) flow and glomerular filtration rate (Dunn et al. 1986; MarinGrez et al. 1986). However, the literature provides discrepant information on the influence of ANP on renal haemodynamics (Abu-Amarah and Balment 1999; Eiskjaer et al. 1996; Garcia-Estan and Roman 1990; Janssen et al. 1994; Semmekrot et al. 1990). It has also been published that an effect of exogenous ANP on renal blood (and plasma) flow and glomerular filtration rate may depend on the age of the examined individuals (Chevalier et al. 1988; Robillard et al. 1988; Semmekrot et al. 1990).

Address for correspondence:

Alicja Dratwa, PhD

Department of Animal Physiology,

Faculty of Biotechnology and Animal Science, Agricultural University of Szczecin Str. Doktora Judyma 6, 71-466 Szczecin, Poland
Phone : +480914541521 ext. 340

Fax: +48091 4541642

E-mail: Alicja.Dratwa@biot.ar.szczecin.pl

http://www.vfu.cz/acta-vet/actavet.htm 
This study was aimed to provide information on the dynamics of changes in the concentration of atrial natriuretic peptide in blood plasma of calves during the first seven days of their life and to find any association between blood plasma ANP concentration and effective renal blood and plasma flow and glomerular filtration rate.

\section{Materials and Methods}

The experiment was carried out on 10 clinically healthy Black-and-White calves during the first seven days of postnatal life. After the necessary zootechnical procedures and feeding colostrum, the calves were transported to the research facility of the Department of Animal Physiology. During the experiment, the animals remained in individual boxes in equal environments. The calves were fed colostrum and $6-7$ litres of maternal milk per day (three times a day).

Before the experiment, Foley balloon catheters had been inserted into the urinary bladders of the calves (each day of the experiment) and their external jugular veins were catheterised. The calves were weighed each day before the samplings that always took place at the same time of the day, one hour after morning feeding (at $9.00 \mathrm{~h}$ ).

The kidney function was analysed by means of clearance tests, using administered test substances. Paraaminohippuric acid (Sigma Chemical Company, St. Louis, MO, USA) was used to measure renal plasma flow, while inulin (Sigma Chemical Company, St. Louis, MO, USA) was used to diagnose plasma glomerular filtration rate.

The analyses started with the collection of a blood $\left(\mathrm{K}_{0}\right)$ and urine $\left(\mathrm{U}_{0}\right)$ sample, which were used as "blind" tests, necessary for further analyses. Thereafter, the calves were intravenously administered $2.5 \mathrm{~g}$ inulin (in $20 \mathrm{ml}$ of $0.9 \%$ $\mathrm{NaCl}$ ), and 20 minutes after inulin administration, $1.5 \mathrm{~g}$ of para-aminohippuric (in $10 \mathrm{ml} \mathrm{H}_{2} \mathrm{O}$ ) was injected. Forty minutes after the inulin injection, urine was collected to polyethylene bags within two periods of time in order to measure per-minute urine flow rate. In the middle of each urine sampling period, blood was collected to ETDA tubes (Vacuette with $1.8 \mathrm{mg}$ ETDA- $\mathrm{K}_{3}$ per $1 \mathrm{ml}$ blood; Greiner Bio- One, Austria), to measure ANP concentration, and to heparin tubes (Heparin, Biochemie, Austria) in order to assay the test substances. Immediately after the blood samplings, haematocrit was measured, which was used in further analyses to calculate renal blood flow. The collected blood samples were immediately centrifuged at $3000 \mathrm{rpm}$ at $4{ }^{\circ} \mathrm{C}$ for $15 \mathrm{~min}$. The resulting plasma was stored at $-20^{\circ} \mathrm{C}$ until further analyses.

Plasma was assayed for ANP and test substances concentrations, while the concentrations of inulin and paraaminohippuric acid were measured in urine. The assays were performed with the following methods:

Atrial natriuretic peptide - radioimmunoassay, based on concentration measurements of ${ }^{125}$ I-labelled ANP, using a Shionoria ANP kit, CIS Bio Intl, France (Clerico 1996).

Haematocrit - micromethod.

Inulin - resorcinol method (Borkowski et al. 1986).

Para-aminohippuric acid - modified Brun's method (W augh and Beall 1974).

In order to comprehensively diagnose the functioning of kidneys, the following were calculated:

effective renal blood flow (ERBF),

clearance of inulin $\left(\mathrm{C}_{\mathrm{in}}\right)$ and para-aminohippuric acid $\left(\mathrm{C}_{\mathrm{PAH}}\right)$.

$$
\mathrm{C}=\frac{\mathrm{U} \cdot \mathrm{V}}{\mathrm{P}}[\mathrm{ml} / \mathrm{min}]
$$

$$
\mathrm{ERBF}=\frac{\mathrm{ERPF}}{1-\mathrm{Ht}}[\mathrm{ml} / \mathrm{min}]
$$

where: C - clearance,

$\mathrm{U} \quad$ - urine concentration [mmol/l],

$\mathrm{P} \quad$ - blood plasma concentration [mmol/l],

$\mathrm{V}$ - diuresis $[\mathrm{ml} / \mathrm{min}]$,

ERBF - effective renal blood flow,

$\mathrm{Ht}$ - haematocrit [1/1],

ERPF - effective renal plasma flow $\left(\mathrm{C}_{\mathrm{PAH}}\right) \quad[\mathrm{ml} / \mathrm{min}]$,

GFR - glomerular filtration rate $\left(\mathrm{C}_{\mathrm{in}}\right)[\mathrm{ml} / \mathrm{min}]$,

The obtained data were standardised per $1 \mathrm{~m}^{2}$ of calf body surface area, according to Meeh's formula (after Ketz 1974):

$$
S=0.105 \cdot \sqrt[3]{b w^{2}}\left[m^{2}\right]
$$

where: $S$ - body surface area;

$$
b w \text { - body weight. }
$$

From the raw results obtained, means and standard deviations were calculated. In order to estimate significance of differences, ANOVA with replications was employed. Relationships between the concentration of atrial 
natriuretic peptide in blood plasma and tested indices of renal function in the subsequent days of calves' postnatal life were estimated using coefficients of correlations. Statistical computations were performed by means of Statistica 6.0 software package.

\section{Results}

Over the first seven days of life, blood plasma ANP concentration in the calves was found to increase significantly $(p \leq 0.01)$. On the first day postpartum, the mean concentration of this hormone was $5.72 \pm 1.34 \mathrm{pmol} / \mathrm{l}$, while on the $7^{\text {th }}$ day it was $14.34 \pm 2.09 \mathrm{pmol} / \mathrm{l}$. The highest blood plasma ANP concentration was recorded on the sixth day (mean $16.43 \pm 1.92 \mathrm{pmol} / \mathrm{l})$. The mean ANP concentration in blood plasma for the first week of life was $11.40 \mathrm{pmol} / \mathrm{l}$ (Table 1$)$.

Table 1. Concentration of atrial natriuretic peptide (ANP), effective renal blood flow (ERBF), effective renal plasma flow (ERPF), and glomerular filtration rate (GFR), diuresis (V)

\begin{tabular}{|c|c|c|c|c|c|c|c|c|c|c|}
\hline & \multirow[t]{2}{*}{ Item } & \multicolumn{7}{|c|}{ Day of life } & \multicolumn{2}{|c|}{$\begin{array}{l}\text { Significance of } \\
\text { differences }\end{array}$} \\
\hline & & 1 & 2 & 3 & 4 & 5 & 6 & 7 & $p \leq 0.01$ & $p \leq 0.05$ \\
\hline \multirow[t]{2}{*}{ ANP } & $\overline{\mathrm{x}}[\mathrm{pmol} / \mathrm{l}]$ & 5.72 & 9.39 & 10.28 & 11.27 & 12.35 & 16.43 & 14.34 & \multirow{2}{*}{$\begin{array}{ll}1 & \rightarrow 4-7 \\
2 & \rightarrow 6 \\
3 & \rightarrow 6 \\
4 \rightarrow & \rightarrow \\
\end{array}$} & \multirow{2}{*}{$\begin{array}{l}l \rightarrow 3 \\
2 \rightarrow 7 \\
5 \rightarrow 6\end{array}$} \\
\hline & $\mathrm{SD}$ & 4.23 & 6.60 & 5.49 & 4.82 & 4.47 & 6.09 & 6.60 & & \\
\hline \multirow[t]{2}{*}{ ERBF } & $\overline{\mathrm{X}}\left[\mathrm{ml} / \mathrm{min} / \mathrm{m}^{2}\right]$ & 280.22 & 310.06 & 336.11 & 306.09 & 289.56 & 313.62 & 338.25 & \multirow{2}{*}{$\begin{array}{l}1 \rightarrow 3,7 \\
3 \rightarrow 5 \\
5 \rightarrow 7\end{array}$} & \multirow{2}{*}{$\begin{array}{l}l \rightarrow 2,4,6 \\
2 \rightarrow 5 \\
3 \rightarrow 4 \\
4 \rightarrow 7 \\
5 \rightarrow 6 \\
\end{array}$} \\
\hline & SD & 32.57 & 26.00 & 33.15 & 18.11 & 18.81 & 29.49 & 43.40 & & \\
\hline \multirow[t]{2}{*}{ ERPF } & $\overline{\mathrm{x}}\left[\mathrm{ml} / \mathrm{min} / \mathrm{m}^{2}\right]$ & 179.77 & 211.17 & 234.82 & 217.71 & 209.65 & 227.22 & 245.22 & \multirow{2}{*}{$\begin{array}{l}1 \rightarrow 2-7 \\
3 \rightarrow 5 \\
5 \rightarrow 7\end{array}$} & \multirow{2}{*}{$\begin{array}{l}2 \rightarrow 3,7 \\
3 \rightarrow 4 \\
4 \rightarrow 7 \\
5 \rightarrow 6\end{array}$} \\
\hline & SD & 26.14 & 21.92 & 21.81 & 18.89 & 17.65 & 22.15 & 31.17 & & \\
\hline \multirow[t]{2}{*}{ GFR } & $\overline{\mathrm{x}}\left[\mathrm{ml} / \mathrm{min} / \mathrm{m}^{2}\right]$ & 35.68 & 49.97 & 52.43 & 49.33 & 53.01 & 49.98 & 51.67 & \multirow[t]{2}{*}{$1 \rightarrow 2-7$} & \multirow[t]{2}{*}{$3 \rightarrow 4$} \\
\hline & SD & 6.63 & 5.56 & 4.51 & 7.41 & 7.33 & 6.20 & 5.89 & & \\
\hline \multirow[t]{2}{*}{ V } & $\overline{\mathrm{x}}\left[\mathrm{ml} / \mathrm{min} / \mathrm{m}^{2}\right]$ & 0.51 & 0.80 & 1.41 & 1.17 & 1.63 & 1.36 & 1.42 & \multirow[t]{2}{*}{$\begin{array}{l}1 \rightarrow 3-6 \\
2 \rightarrow 5\end{array}$} & \multirow[t]{2}{*}{$\begin{array}{l}2 \rightarrow 3,4,6 \\
4 \rightarrow 5\end{array}$} \\
\hline & SD & 0.28 & 0.43 & 0.82 & 0.57 & 0.58 & 0.38 & 1.16 & & \\
\hline
\end{tabular}

The mean renal blood flow (ERBF) and mean plasma flow (ERPF) during the first week of life remained at a low level and showed variations, mean ERBF ranging within $280.22 \pm 10.30$ and $338.25 \pm 13.72 \mathrm{ml} / \mathrm{min} / \mathrm{m}^{2}$ and ERPF ranging between $179.77 \pm 8.27$ and $245.22 \pm 9.86$ $\mathrm{ml} / \mathrm{min} / \mathrm{m}^{2}$ (Table 1). The values of these indices differed significantly $(p \leq 0.05)$ between individual days of the experiment. What should be emphasised, both renal blood and renal plasma flow increased significantly $(p \leq 0.01)$ within the first three days. Changes in ERBF between individual days were correlated $(p \leq 0.01)$ with those in ERPF. No statistically significant correlations $(p \leq 0.05)$ were found between changes in ANP concentration and ERBF or ERPF.

The observed average glomerular filtration rate during the first seven days of life in calves was $48.87 \mathrm{ml} / \mathrm{min} / \mathrm{m}^{2}$ (Table 1). The mean GFR was the lowest during the first day, $35.68 \pm 2.10 \mathrm{ml} / \mathrm{min} / \mathrm{m}^{2}$. The mean glomerular filtration rate was observed to significantly $(p \leq 0.01)$ increase on the second day, up to $49.97 \pm 1.76 \mathrm{ml} / \mathrm{min} / \mathrm{m}^{2}$, to stabilise over the remaining days of the first week of life at a mean level of $51.06 \mathrm{ml} / \mathrm{min} / \mathrm{m}^{2}$. It should be noted that no correlation $(p \leq 0.05)$ was found during the first week of life between the renal blood (plasma) flow and the glomerular filtration rate.

\section{Discussion}

The increase in the concentration of ANP in blood plasma with age has been confirmed also by Tulassay et al. (1987), who reported a low concentration of atrial natriuretic 
peptide in the first hour postpartum $(22.1 \mathrm{fmol} / \mathrm{l})$ in human neonates, followed by a significant increase in ANP concentration until the third day of life (45.2 fmol/l). Also, Gemelli et al. (1991) found a significant increase in ANP concentration in the blood plasma of human neonates within the first 24 hours of life.

A reverse trend in the changes in atrial natriuretic peptide concentration in blood plasma of calves was observed by Takemura et al. (1994). The highest concentration of the hormone was recorded after birth $(62.7 \mathrm{pmol} / \mathrm{l})$, while the lowest on the $10^{\text {th }}$ day of age $(11.3$ pmol/l). Also Amadieu-Farmakis et al. (1988a; 1988b) observed the highest ANP concentration in calf blood plasma directly upon birth $(20 \mathrm{pmol} / \mathrm{l}$ on average $)$ and a decrease in the concentration until the third day of age $(16.5 \mathrm{pmol} / \mathrm{l})$. In the remaining days of the first week of life, the authors found a slightly growing trend.

A number of factors may have influenced the increase in blood plasma ANP concentration with age of the calves observed in our experiment. It is known that the main factors causing an increased release of atrial natriuretic peptide include increased volume and/or pressure of circulating blood (Chapman et al. 1998; Chevalier et al. 1990a; Grant et al. 1996; Takemura et al. 1990). Chevalier et al. (1990b) have demonstrated that the renal response to ANP during the neonatal period in rats, after an experimental increase in blood plasma volume, increases with age. It has also been demonstrated that the total water volume in a calf during the first week of life is high and reaches on average $80 \%$ of the body weight (Skrzypczak 1991).

The increase in atrial natriuretic peptide concentration in blood plasma during the first week of neonatal life of calves observed in our experiment may have probably resulted from enhanced synthesis and release of ANP. This is confirmed by the results reported by Silberbach et al. (1991), who studied one- and seven-day-old lambs.

Available literature does not provide clear information on a possible effect of atrial natriuretic peptide on renal blood or plasma flow. Neither does it inform on a possible reverse effect of changes in ERBF or ERPF on ANP concentration in blood. It is possible that the reasons for the increased renal blood and plasma flow observed in our experiment during the first three days of life may include elevated ANP concentration in blood plasma; however the coefficient of correlation between these indices proved non-significant $(p \leq 0.05)$. This suggestion has been confirmed by Nushiro et al. (1987), Seino et al. (1988), who studied adult rabbits, and Kimura et al. (1986), who experimented on adult dogs, and who have demonstrated that intravenously administered exogenous ANP triggers a growth in ERBF (ERPF). Using a similar experimental design, Ei skjaer et al. (1996) and Janssen et al. (1994) in adult humans, as well as Semmekrot et al. (1990) in rabbits, observed these indices to decrease. On the other hand, no changes in renal blood (plasma) flow were found by Brown and Corr (1987) in humans, and by Dunn et al. (1986) and Garcia-Estan and Roman (1990) in adult rats.

So far, it has not been clearly established whether and how atrial natriuretic peptide affects renal plasma filtration (Abu-Amarah and Balment 1999; Bidiville et al. 1988; Chevalier et al. 1988; Garcia-Estan and Roman 1990; Janssen et al. 1994; Robillard et al. 1988; Seino et al. 1988; Semmekrot et al. 1990). In our experiment, a lack of relationship was demonstrated between changes in ANP concentration in blood and glomerular filtration rate (coefficient of correlation non-significant at $p \leq 0.05$ ). This also shows that a statistically significant increase in ANP concentration in the blood plasma of calves on the sixth day of life did not cause a significant change in the glomerular filtration rate. Lack of effect of ANP on GFR has been also confirmed in studies on adult humans (Bidville et al. 1988), dogs (Kimura et al. 1986), rats (Abu-Amarah and Balment 1999, Garcia-Estan and Roman 1990), lambs (Robillard et al. 1988), and young rats (Chevalier et al. 1988). The above-mentioned results may support the suggestion by 
Granger (1998) that the lack of changes in the glomerular filtration rate results from ANP "redirecting" blood into the medullary part of the kidneys. Conversely, Janssen et al. (1994) in adult humans, Robillard et al. (1988) in adult sheep, Se ino et al. (1988) in adult rabbits, and Chevalier et al. (1988) in adult rats, observed an increased glomerular filtration rate after administration of exogenous ANP. According to Du n et al. (1986) and Marin-Grez et al. (1986), enhanced GFR may be a result of haemodynamics changes in the blood vessels of the glomeruli which lead to elevated glomerular filtration pressure. Conversely, Semmekrot et al. (1990) observed decreasing GFR in young (4 - 11 days old) and adult rabbits.

The results of this study show that in calves during the first seven days of postnatal life endogenous ANP did not change the effective renal blood (plasma) flow and glomerular filtration rate.

\section{Natriuretický peptid a hemodynamika v ledvinách u novorozených jehňat}

Cílem studie bylo prozkoumat dynamické změny v koncentraci atriového natriuretického peptidu (ANP) v krevní plazmě u jehňat během prvních sedmi dní po narození a prostudovat vztah mezi koncentrací ANP v krevní plazmě, průtokem krve (ERBF) a krevní plasmy (ERPF) ledvinami, rychlostí glomerulární filtrace (GRF). Pokus byl proveden na deseti klinicky zdravých, černobílých jehňatech během prvních sedmi dní po narození. Koncentrace ANP v krevní plazmě byla zjištována pomocí radioimunoanalýzy (RIA). Funkce ledvin byla hodnocena pomocí clearance s využitím kyseliny paraaminohippurové a inulinu. Koncentrace ANP v plasmě se $s$ věkem zvyšovala. První den byla průměrná koncentrace ANP $5,72 \pm 1,34 \mathrm{pmol} \cdot \mathrm{l}^{-1}$, sedmý den pak $14,34 \pm 2,09 \mathrm{pmol} \cdot \mathrm{l}^{-1}$. ERBF a ERPF se během prvního týdne života měnily. Průměrný ERBF se pohyboval v mezích $280,22 \pm 10,30 \mathrm{ml} \cdot \mathrm{min}^{-}$ ${ }^{1} \cdot \mathrm{m}^{-2}\left(1\right.$. den) a $338,25 \pm 13,72 \mathrm{ml} \cdot \mathrm{min}^{-1} \cdot \mathrm{m}^{-2}$ (7. den), ERPF pak v mezích $179,77 \pm 8,27$ $\mathrm{ml} \cdot \mathrm{min}^{-1} \cdot \mathrm{m}^{-2}\left(1\right.$. den) a $245,22 \pm 9,86 \mathrm{ml} \cdot \mathrm{min}^{-1} \cdot \mathrm{m}^{-2}(7$. den). Průměrná GRF byla první den $35,68 \pm 2,10 \mathrm{ml} \cdot \mathrm{min}^{-1} \cdot \mathrm{m}^{-2}$ a signifikantně se zvýšila druhý den: $49,97 \pm 1,76 \mathrm{ml} \cdot \mathrm{min}^{-1} \cdot \mathrm{m}^{-2}$ ( $p \mathrm{~L} 0,01$ ), následující dny se stabilizovala na průměrné hodnotě $51,06 \mathrm{ml} \cdot \mathrm{min}^{-1} \cdot \mathrm{m}^{-2}$. Studie ukázaly, že neexistuje žádný vztah mezi koncentrací ANP v plazmě, ERPF (ERBF) a GRF. Tyto výsledky nasvědčují tomu, že během prvního týdne po narození endogenní ANP u jehňat neovlivňuje průtok krve (krevní plazmy) ledvinami ani rychlost glomerulární filtrace.

\section{Acknowledgments}

The author wishes to thank Prof. Wieslaw F. Skrzypczak (Head of Department of Animal Physiology, Faculty of Biotechnology and Animal Science, Agricultural University of Szczecin) for his critical reading and helpful comments on the manuscript. The author acknowledges Dr Malgorzata Ozgo for her help in the searches made.

The project was financed by the Ministry of Scientific Research and Information Technology, grant no. 3PO6D 02822

\section{References}

ABU-AMARAH I, BALMENT RJ 1999: Vascular, renal, and endocrine responses to low-dose atrial natriuretic peptide in the fluid- balanced New Zealand genetically hypertensive rats with and without endogenous arginine vasopressin. Can J Physiol Pharmacol 77: 102-110

AMADIEU-FARMAKIS M, BARLET JP, GIRY J, KATI-COULIBALY S 1988a: Plasma atrial natriuretic peptide (ANP) and vasopressin changes in calves during the postnatal period. J Physiol 406: 131

AMADIEU-FARMAKIS M, GIRY J, BARLET JP 1988b: Increase in plasma concentrations of atrial natriuretic peptide during infusion of hypertonic saline in conscious newborn calves. J Endocrinol 119: 23-29

BIDIVILLE J, WAEBER G, PORCHET M, NUSSBERGER J, BIOLLAZ J, GOMEZ H, CALLAHAN L, WAEBER B, BRUNNER HR 1988: Haemodynamic, renal, and endocrine effects of 4-h infusions of human atrial natriuretic peptide in normal volunteers. Fundam Clin Pharmacol 2: 413-429

BORKOWSKI T, BORKOWSKA-MADECKA I, MODRZEWSKA R 1986: Functional Tests in Laboratory Diagnostics. PZWL, Warszawa [In Polish]. 
BROWN J, CORR L 1987: Renal mechanisms of human alpha-atrial natriuretic peptide in man. J Physiol-London 387: $31-46$

CHAI SY, SEXTON PM, ALLEN AM, FIGDOR R, MENDELSOHN FA 1986: In vitro autoradiographic localization of ANP receptors in rat kidney and adrenal gland. Amer J Physiol Renal Physiol 250: F753- F757

CHAPMAN AB, ABRAHAM WT, ZAMUDIO S, COFFIN C, MEROUANI A, YOUNG D, JOHNSON A, OSORIO F, GOLDBERG C, MOORE LG, DAHMS T, SCHRIER RW 1998: Temporal relationships between hormonal and haemodynamic changes in early human pregnancy. Kidney Int 54: 2056-2063

CHEVALIER RL, GOMEZ RA, CAREY RM, PEACH MJ, LINDEN JM 1988: Renal effects of atrial natriuretic peptide infusion in young and adult rats. Pediatr Res 24: 333-337

CHEVALIER RL, THORNHILL B, GOMEZ RA, RAGSDALE NV, PEACH MJ, CAREY RM 1990a: Role of atrial natriuretic peptide in the response to blood volume expansion in the weanling rat. Pediatr Res 27: 396- 400

CHEVALIER RL, THORNHILL BA, PEACH MJ, CAREY RM 1990b: Hematocrit modulates response of ANP to volume expansion in immature rats. Amer J Physiol 258(3 Pt 2): R729-735

CLERICO A, IERVASI G, DEL CHICCA MG, MAFFEI S, BERTI S, SABATINO L, TURCHI S, CAZZUOLA F, MANFREDI C, BIAGINI A 1996: Analytical performance and clinical usefulness of commercially available IRMA kits for measuring atrial natriuretic peptide in patients with heart failure. Clin Chem 42: 1627-1633

DUNN BR, ICHIKAWA I, PFEFFER JM, TROY JL, BRENNER BM 1986: Renal and systemic haemodynamic effects of synthetic atrial natriuretic peptide in the anaesthetized rat. Circ Res 59: 237-246

EISKJAER H, NIELSEN CB, SORENSEN SS, PEDERSEN EB 1996: Renal and hormonal actions of atrial natriuretic peptide during angiotensin II or noradrenaline infusion in man. Eur J Clin Invest 26: 584- 595

GARCIA-ESTAN J, ROMAN RJ 1990: Role of renal interstitial hydrostatic pressure in natriuretic response to ANP. Amer J Physiol 258: 1333-1339

GEMELLI M, MAMI C, DE LUCA F, STELITANO L, BONACCORSI P, MARTINO F 1991: Atrial natriuretic peptide and rennin-aldosterone relationship in healthy newborn infants. Acta Paedriatr Scand 80: 1128-1133

GRANGER JP 1998: Regulation of extracellular fluid volume by integrated control of sodium excretion. Adv Physiol Educ 20: $157-168$

GRANT SM, GREEN HJ, PHILLIPS SM, ENNS DL, SUTTON JR 1996: Fluid and electrolyte hormonal responses to exercise and acute plasma volume expansion. J Appl Physiol 81: 2386-2392

HEALY DP, FANESTIL DD 1986: Localization of atrial natriuretic peptide binding sites within the rat kidney. Amer J Physiol 250: 573-578

JANSSEN WM, DE ZEEUW D, VAN DER HEM GK, DE JONG PE 1994: Renal tubular sensitivity to atrial natriuretic factor in essential hypertension. J Hypertension 12: 439-447

KETZ HA 1974: Physiology of the kidney. In: KOLB E (Ed.).: Textbook of domestic animals physiology. Veb Gustav Fischer Verlag Jena, pp. 619-652 [In German].

KIMURA T, ABE K, SHOJI M, TSUNODA K, MATSUI K, OTA K, INOUE M, YASUJIMA M, YOSHINAGA K 1986: Effects of human atrial natriuretic peptide on renal function and vasopressin release. Amer J Physiol 250: 789-794

LYNCH DR, BRAAS KM, SNYDER SH 1986: Atrial natriuretic factor receptors in rat kidney, adrenal gland, and brain: autoradiographic localization and fluid balance dependent changes. Proc Natl Acad Sci USA 83: 3357336

MARIN-GREZ M, FLEMING JT, STEINHAUSEN M 1986: Atrial natriuretic peptide causes pre-glomerular vasodilatation and post-glomerular vasoconstriction in rat kidney. Nature 324: 473-476

NUSHIRO N, ABE K, SEINO M, ITOH S, YOSHINAGA K 1987: The effect of atrial natriuretic peptide on renal function and the rennin- aldosterone system in anaesthetized rabbits. Tohoku J Exp Med 152 : 301-310

ROBILLARD JE, NAKAMURA KT, VARILLE VA, ANDRESEN AA, MATHERNE GP, VAN ORDEN DE 1988: Ontogeny of the renal response to natriuretic peptide in sheep. Amer J Physiol 254: 634-641

RUTHERFORD RAD, MATSUDA Y, WILKINS MR, POLAK JM, WHARTON J 1994: Identification of renal natriuretic peptide receptor subpopulations by use of the non-peptide antagonist, HS-142-1. Brit J Pharmacol 113: $931-939$

SEINO M, ABE K, NUSHIRO N, YOSHINAGA K 1988: Nifedipine enhances the vasodepressor and natriuretic effects of atrial natriuretic peptide. Hypertension 11: $34-40$

SEMMEKROT BA, WIESEL PH, MONNENS LA, GUIGNARD JP 1990: Age differences in renal response to atrial natriuretic peptide in rabbits. Life Sci 46: 849-856

SILBERBACH M, STEJSKAL E, FOKER J, BIANCO R, TOBIAN L, BURNETT JC JR, EINZIG S 1991: Newborn cardiorenal dynamics: a state of atrial natriuretic peptide unresponsiveness. Amer J Physiol 261: 20692074

SKRZYPCZAK WF 1991: Size of water spaces and selected renal function indices during the first week of postnatal life of calves. Professorship dissertation. Szczecin, 136 p. [In Polish].

TAKEDA S, KUSANO E, MURAYAMA N, ASANO Y, HOSODA S, SOKABE H, KAWASHIMA H 1986: Atrial natriuretic peptide elevates cGMP contents in glomeruli and in distal tubular of rat kidney. Biochem Biophys Res Commun 136: 947-954

TAKEMURA N, KOYAMA H, SAKO T, ANDO K, MOTOYOSHI S, MARUMO F 1990: Bovine atrial natriuretic peptide in heart failure. J Endocrinol 124: 463-467 
TAKEMURA N, KOYAMA H, SAKO T, SUZUKI K, MOTOYOSHI S 1994: Plasma atrial natriuretic peptide in normal calves during the first 10 days of life. Res Vet Sci 57: 251-252

TULASSAY T, SERI I, RASCHER W 1987: Atrial natriuretic peptide and extracellular volume contraction after birth. Acta Paediatr Scand 76: 444-446

WAUGH WH, BEALL PT 1974: Simplified measurement of p-aminohippurate and other arylamines in plasma and urine. Kidney Int 5: 429-436

WILCOX JN, AUGUSTINE A, GOEDDEL DV, LOWE DG 1991: Differential regional expression of the three natriuretic peptide receptor genes within primate tissues. Mol Cell Biol 11: 3454-3462 